\title{
Proprioceptive neuromuscular facilitation and strength training to gain muscle strength in elderly women
}

\author{
Facilitação neuromuscular proprioceptiva e musculação para ganho de força muscular em idosas
}

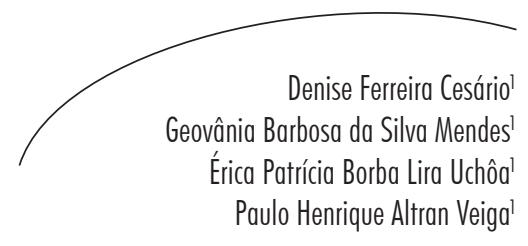

Abstract

Introduction: The world population is aging, and this leads to progressive physiological changes and increased incidence of acute and chronic degenerative diseases. In this sense, one of the main changes occurring during this period is sarcopenia, characterized by decreased skeletal muscle mass. Objective: To perform comparative analyze of results of proprioceptive neuromuscular facilitation (PNF) techniques and strength training to gain muscle strength of biceps and quadriceps and grip in the elderly. Method: This is a prospective randomized study with purposive sample of 17 elderly patients undergoing a program of strength training and evaluation with a dynamometer, before and after applying the treatment protocol. After evaluation, subjects were randomly divided into two groups: PNF and Bodybuilding. Results: The group trained with PNF had more significant gain in muscle strength, biceps $\left(p=0.0392^{*}\right)$ and quadriceps $(p=0.0230 *)$ did not show statistically significant relevance in the grip $(p=0.1075)$. In the group trained with weights there was no statistically significant difference: biceps $(p=0.5338)$, quadriceps femoris $(\mathrm{p}=0.0679)$ and palmar $(\mathrm{p}=0.3758)$. Comparing both techniques, however, there was no statistical difference: biceps $(p=0.5739)$, quadriceps $(p=0.8450)$ and palmar ( $\mathrm{p}=0.2457)$. Conclusion: This study showed that the period of 12 weeks of intervention seems to be sufficient to achieve gains in muscle strength with PNF technique, but when comparing the two techniques it was not statistically significant.

\section{Resumo}

Introdução: A população mundial está envelhecendo, o que acarreta alterações fisiológicas progressivas e aumento da incidência de doenças agudas e crônicodegenerativas. Nesse sentido, uma das principais alterações que ocorre nesse período é a sarcopenia, caracterizada pela diminuição da massa muscular esquelética. Objetivo: Analisar comparativamente os resultados das técnicas de Facilitação Neuromuscular

Key words: Muscle Strength. Aging. Physical therapy Specialty.

\footnotetext{
Curso de Fisioterapia, Centro de Ciências Biológicas e da Saúde. Universidade Católica de Pernambuco. Recife, PE, Brasil.
} 
Proprioceptiva (FNP) e musculação para ganho de força dos músculos bíceps braquial e quadríceps femoral e preensão palmar em idosas. Método: Trata-se de estudo prospectivo, randomizado com amostra intencional de 17 idosas submetidas a um programa de treinamento de força e avaliação com dinamômetro, antes e após aplicação do protocolo de tratamento. Após a avaliação, os indivíduos foram divididos aleatoriamente em dois grupos: FNP e Musculação. Resultados: O grupo treinado com FNP apresentou ganho de força mais expressivo no músculo, bíceps braquial $\left(\mathrm{p}=0,0392^{*}\right)$ e quadríceps femoral $\left(\mathrm{p}=0,0230^{*}\right)$, não apresentando relevância estatística significante na preensão palmar $(\mathrm{p}=0,1075)$. No grupo treinado com musculação, não houve diferenças estatisticamente significantes: bíceps braquial ( $\mathrm{p}=0,5338)$, quadríceps femoral $(p=0,0679)$ e na preensão palmar $(p=0,3758)$. Na comparação entre as duas técnicas, porém, não foram observadas diferenças estatísticas: bíceps $(p=0,5739)$, quadríceps $(\mathrm{p}=0,8450)$ e preensão palmar $(\mathrm{p}=0,2457)$. Conclusão: $O$ presente estudo demonstrou que o período de 12 semanas de intervenção parece ser suficiente para conseguir ganhos de força muscular com a técnica de FNP; entretanto, quando as duas técnicas foram comparadas, não houve diferença estatisticamente significante.
Palavras-chave: Força muscular. Envelhecimento. Fisioterapia.

\section{INTRODUCTION}

Ageing is part of life, and in that sense, there are physiological changes and progressive increase in the incidence of acute and chronic degenerative diseases. ${ }^{1,2}$ Thus, one of the main gradual changes occurring in this period is sarcopenia, which is characterized by decreased skeletal muscle mass by $40 \% .^{3}$ This change has significant impact on public health, since there is great demand in hospitals, due to functional disabilities generated in this aging population.

Muscle strength is essential for carrying out activities of daily living. ${ }^{4}$ Among the elderly, there is loss of muscle mass, which is directly related to strength, thus causing the physical deconditioning. ${ }^{5}$ Muscle strength is also important to maintain homeostasis and hemodynamics in daily life. When this force is reduced, it may be the main cause responsible for the degradation of mobility and functional capacity of the elderly. ${ }^{6}$

Several studies explain the changes in muscle structure and functional decline that occur with aging. ${ }^{7-9}$ In fact, some authors believe that decreases occur in quantity and size of the phasic fibers (type II), with lower intensity of tonic fibers atrophy (type I). It is understood today that the strength of a muscle is related to its size, its cross-sectional area and the distribution of muscle fiber types, and the amount of motor units activated. When is a compromise of these components, it can lead to decreased strength. ${ }^{10,11}$

The physical therapy intervention with exercise can be an effective and safe measure to minimize the physiological effects that occur over age. Therapeutic exercises can help to gain muscle strength in elderly patients and thus improve their fitness. The elderly usually finds it difficult to carry out basic activities as bathing and dressing, walking short distances, and have an increased risk of falls, which, at that age, can cause serious fractures. Therefore, the inclusion of physical exercise, according to the Brazilian Society of Sports Medicine (SBME) and the Brazilian Society of Geriatrics and Gerontology (SBGG), in the routine of the elderly is important. It is known that the force is reversed with implementation of a protocol of adequate training, thus improving functional capacity, independence and life expectancy of the elderly. ${ }^{12,13}$

Among the therapeutic modalities used to gain muscle strength, is the work of resistance, the most known is bodybuilding, which is used in resistance with different loads and ranges of movement. These muscle contractions can vary according to the needs of the individual, and 
the more used are the isometric and isotonic contractions, which may be mild or intense, with aerobic or anaerobic resources. ${ }^{14}$

Besides bodybuilding, the technique of proprioceptive neuromuscular facilitation (PNF), widely used in rehabilitation, has gained high visibility. The PNF is based on the application of resistance to facilitate muscular contraction. ${ }^{15}$ This method has as main purpose achieving individual needs, and thus promotes functional movement, through the facilitation, inhibition, strengthening and relaxation of muscle groups. Additionally, PNF supports synchronization and coordination training of movement, improves activities of daily living and quality of life. This technique uses concentric, eccentric and static muscle contractions, combined with resistance graded facilitator and procedures, as diagonal movement patterns and application of sensory stimulus, auditory, visual, proprioceptive and skin stimuli, leading to a maximum of the neuromuscular apparatus. ${ }^{16,17}$

This study aims at comparatively evaluate the results of the techniques of Proprioceptive Neuromuscular Facilitation (PNF) and bodybuilding for strength gain of biceps and quadriceps musclea and handgrip in elderly women.

\section{MATERIALS AND METHODS}

The research work was conducted in the school clinic of a university in Pernambuco, from September 2010 to April 2011, and was conducted with financial support, through the PIBIC, and was approved by the Ethics Committee under registration CEP 079/2009 and CAAE0046.0.096.000-09.

This is a prospective study with purposive sample of 17 elderly, or not practicing physical activities. Among the inclusion criteria are being over 60 years and being female; and the exclusion criteria comprise neuromuscular diseases, mental deficit and severe osteoporosis.
In the first stage of the project, the elderly were asked about any research methodology, and being aware of the procedures, signed an Informed Consent Form (ICF). Soon after, assessment was carried out with the socio-economic personal data (name, age, marital status, weight, height, occupation, address, telephone, clinical diagnosis, chief complaint, history of present illness) in addition to vital signs.

We also assessed the strength with a dynamometer, of upper and lower limbs, before and after application of strength training protocol. For the upper limbs, we evaluated the strength of the biceps and used the Smedley dynamometer ${ }^{\circledR}$, hand and spine. This evaluation was performed with the patient sitting in a chair, with 90 degrees of hip flexion and knee with back support. To assess the strength of the biceps, the subject was asked to flex the elbow "pulling" the dynamometer as hard as he could. Likewise, assessment of the palmar was conducted asking the subject to close her hand, squeezing the dynamometer as hard as possible and also to assess the strength of the quadriceps muscles with the patient seated and the dynamometer positioned to resist knee extension of the individual.

All subjects performed three sets, with the purpose of training and awareness of the movement to be assessed. In the second stage, after the evaluation of the biceps, quadriceps and grip, the subjects were divided randomly by lottery into two groups: one with nine subjects who underwent physical therapy to strengthen PNF (Facilitation group - FG) and another group with eight subjects, who underwent conventional weight training the biceps and the quadriceps of the dominant hand (Bodybuilding group - BD). Then, all sample subjects underwent a program, three times a week for three months.

The FG was subjected to a standard protocol with an upper limb and lower limb standard with three sets of 10 repetitions on each member. The standards for upper limb were (start): Shoulder extension, adduction, shoulder internal rotation of shoulder, wrist flexion and finger flexion; 
(final): shoulder flexion, shoulder abduction, shoulder external rotation, extension wrist and finger extension. For the lower limbs were carried out (early): hip extension, hip adduction, external rotation, knee extension and fingers; (final): hip flexion, hip abduction, internal rotation, knee flexion and fingers.

The BG was submitted to the protocol for the upper limb with three exercises: flexion and extension, shoulder flexion and elbow extension and shoulder abduction and adduction and leg flexion and knee extension, hip abduction and adduction. The load used started with $0.5 \mathrm{~kg}$ to reach $2 \mathrm{~kg}$. All exercises were performed on three sets of 10 repetitions. In a third moment, after a period of strength training, all participants repeated dynamometry assessments.

Categorical variables were presented by their frequencies and percentages, and continuous variables as mean and standard deviation. There was the normal distribution for quantitative variables, by Komogorov-Smirnov test. We used the paired Student $t$ test to analyze differences in the same group; the unpaired Student $t$ test and ANOVA One-Way, were considered in the analysis to compare the bodybuilding group and the group that carried out PNF. We considered the significance level where $p$-value $\leq 0.05$. Data were entered in the Excel spreadsheet software and to obtain the statistical calculations we used GraphPad Prism version 4.0.

\section{RESULTS}

The sample consisted of 17 elderly women who were divided into two groups. FG was composed of nine elderly to age $68.7 \pm 6.2$, and $33.3 \%$ elderly with rheumatoid arthritis, $11.1 \%$ with knee osteoarthritis, diabetic 11.1\%, 33.3\% hypertensive, $11.1 \%$ tendinitis in the shoulder and $11.1 \%$ with a Body Mass Index (BMI) greater than ideal. With regard to marital status, 3 and 6 were married widows. BG was composed of eight elderly aged $68.1( \pm 7.1)$, and $12.5 \%$ with knee osteoarthritis, 25\% diabetes mellitus, low back pain $12.5 \%, 12.5 \%$ hypertensive and $25 \%$ weight above the ideal. With regard to marital status, three were married, one divorced and 5 widowed.

In tables 1 and 2, we can observe an increase in average gain in strength in PNF technique, and also in the group that performed the weight-training, however, less intense. Table 1 shows that in the bodybuilding group, there was no statistically significant differences: biceps $(\mathrm{p}=0.5338)$ and quadriceps $(\mathrm{p}=0.0679)$ and palmar $(\mathrm{p}=0.3758)$. Table 2 shows that the group trained with PNF showed a statistically significant gain in strength in the biceps brachii $(p=0.0392 *)$, quadriceps femoris $(p=0.0230 *)$, and not significant in the grip (0.1075). Table 3 shows that when comparing both techniques, there were no statistical differences, biceps (0.5739) and quadriceps (0.8450) and palmar (0.2457).

Table 1. Comparison of strength between the pre and post-weight-training, showing the distribution of paired differences of mean and standard deviation in $\mathrm{kg}$, the value of $t$ and $\mathrm{p}$-value of the biceps, quadriceps and grip. Recife-PE, 2010-2011.

\begin{tabular}{lcccc}
\hline & $\begin{array}{c}\text { Bodybuilding (Pre) } \\
\text { Mean } \pm \text { SD } \\
(\mathrm{Kg})\end{array}$ & $\begin{array}{c}\text { Bodybuilding (Post) } \\
\text { Mean } \pm \text { SD } \\
(\mathrm{Kg})\end{array}$ & $\mathrm{t}$ & p-value \\
\hline Biceps & $13.50 \pm 4.6$ & $13.71 \pm 4.4$ & 0.65 & 0.5338 \\
Quadriceps & $16.57 \pm 8.0$ & $17.57 \pm 8.3$ & 2.22 & 0.0679 \\
Grip & $21.57 \pm 4.2$ & $22.29 \pm 5.7$ & 0.95 & 0.3758 \\
\hline
\end{tabular}

$\mathrm{SD}=$ standard deviation; $\mathrm{kg}=$ kilograms. Student's $t$ test for paired samples.

$*$ Statistically significant difference p-value $<0.05 \%$. 
Table 2. Comparison of strength between the pre and post-training with PNF, showing the distribution of paired differences of mean and standard deviation in $\mathrm{kg}$, the value of $t$ and $\mathrm{p}$-value of the biceps, quadriceps and grip. Recife-PE, 2010-2011.

\begin{tabular}{lcccc}
\hline & $\begin{array}{c}\text { PNF (Pre) } \\
\text { Mean } \pm \text { SD } \\
(\mathrm{Kg})\end{array}$ & $\begin{array}{c}\text { PNF (Post) } \\
\text { Mean } \pm \text { SD } \\
(\mathrm{Kg})\end{array}$ & $\mathrm{t}$ & p-value \\
\hline Biceps & $11.15 \pm 3.4$ & $13.00 \pm 4.5$ & 2.41 & $0.0392^{*}$ \\
Quadriceps & $14.95 \pm 4.2$ & $17.10 \pm 6.1$ & 2.73 & $0.0230^{*}$ \\
Grip & $18.80 \pm 2.0$ & $20.10 \pm 2.8$ & 22.03 & 0.1075 \\
\hline
\end{tabular}

$\mathrm{SD}=$ standard deviation; $\mathrm{kg}=$ kilograms. Student's $t$ test for paired samples.

$*$ Statistically significant difference $\mathrm{p}$-value $<0.05 \%$.

Table 3. Comparison between the post-bodybuilding and PNF training, showing the mean and standard force in $\mathrm{kg}$, and the value of KS p-value of the biceps, quadriceps and grip. Recife-PE, 2010-2011.

\begin{tabular}{lccccc}
\hline & $\begin{array}{c}\text { Bodybuilding } \\
\text { Mean Post } \mathrm{kg}( \pm \mathrm{SD})\end{array}$ & $(\mathrm{KS})$ & $\begin{array}{c}\text { FNP } \\
\text { Mean Post }(\mathrm{kg})\end{array}$ & & $(\mathrm{KS})$ \\
\hline Biceps & $13.71 \pm 4.46$ & 0.2438 & $13.00 \pm 4.51$ & 0.1711 & 0.5739 \\
Quadriceps & $17.57 \pm 8.30$ & 0.1542 & $17.10 \pm 6.17$ & 0.2103 & 0.8450 \\
Grip & $22.29 \pm 5.73$ & 0.2397 & $20.10 \pm 2.88$ & 0.1862 & 0.2457 \\
\hline
\end{tabular}

$\mathrm{SD}=$ standard deviation; $\mathrm{kg}=$ kilograms; $\mathrm{KS}=$ Komogorov Smirnov (distance). One-Way ANOVA.

$*$ Statistically significant difference p-value $<0.05 \%$.

The following graphs show that in all groups trained with PNF, strength gain was more significant. Figure 1 shows the behavior of the biceps muscle strength, pre-PNF $(11.15 \pm 3.4 \mathrm{~kg})$ and post-PNF $(13.00 \pm 4.5 \mathrm{~kg})$, and in the gym, although there was increase in strength, it was smaller, pre-BD $(13.50 \pm 4.6 \mathrm{~kg})$ and after BD

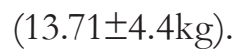




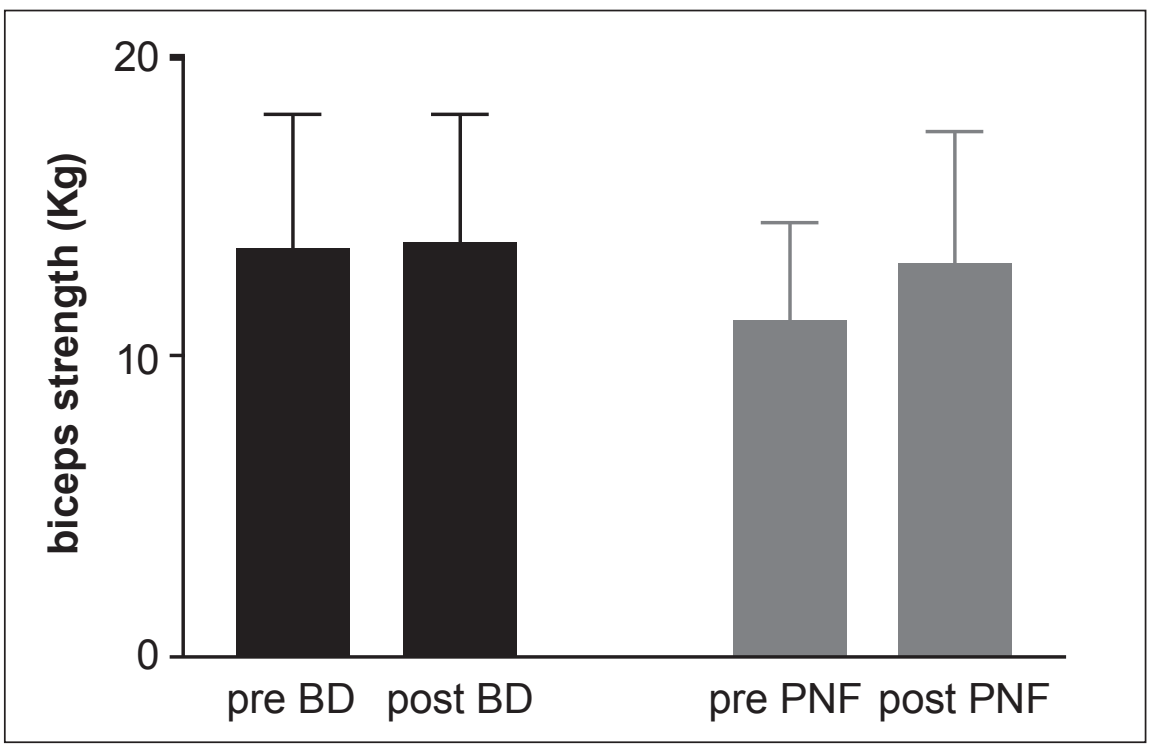

Figure 1. Comparison of strength gains in biceps muscle before and after training between the PNF and weight training.

$\mathrm{BD}=$ bodybuilding $\mathrm{PNF}=$ proprioceptive muscular facilitation

Recife/PE - 2011.

Figure 2 shows the behavior of the strength of the quadriceps muscle, pre-PNF $(14.95 \pm 4.2 \mathrm{~kg})$ and post-PNF $(17.10 \pm 6.1 \mathrm{~kg})$, and in the gym, although there was increase in strength, it was smaller, pre $(16.57 \pm 8.0 \mathrm{~kg})$ and after $(17.57 \pm 8.3 \mathrm{~kg})$. The authors noted, however, increasing muscle strength when comparing the study groups. The following charts show that in all groups trained with PNF strength gain was more significant.

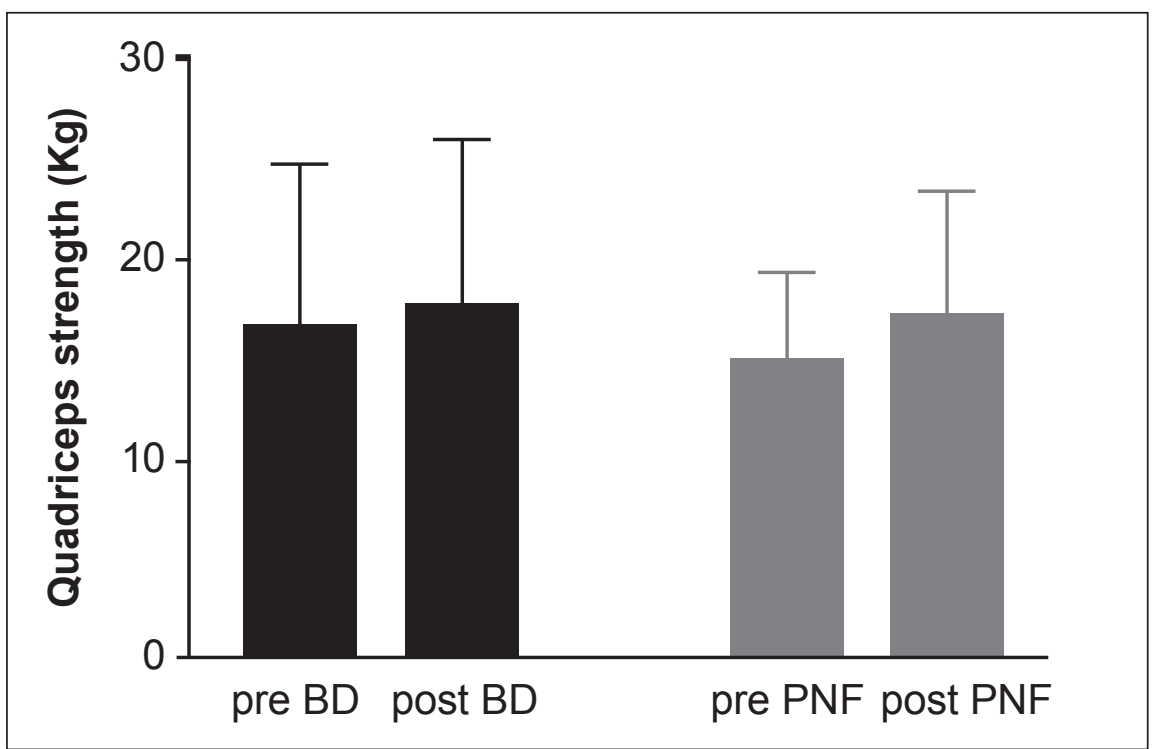

Figure 2. Comparison of gain of strength of the quadriceps muscle in the pre and post training between the PNF and weight training.

$\mathrm{BD}=$ bodybuilding $\mathrm{PNF}=$ proprioceptive neuromuscular facilitation

Recife/PE - 2011. 
Figure 3 shows the behavior of the strength of grip, pre-PNF $(18.80 \pm 2.0 \mathrm{~kg})$ and post-PNF $(20.10 \pm 2.8 \mathrm{~kg})$, and in the gym, although there was increase in strength, this was smaller, preBD $(21.57 \pm 4.2 \mathrm{~kg})$ and after BD (22.29 $\pm 5.7 \mathrm{~kg})$.

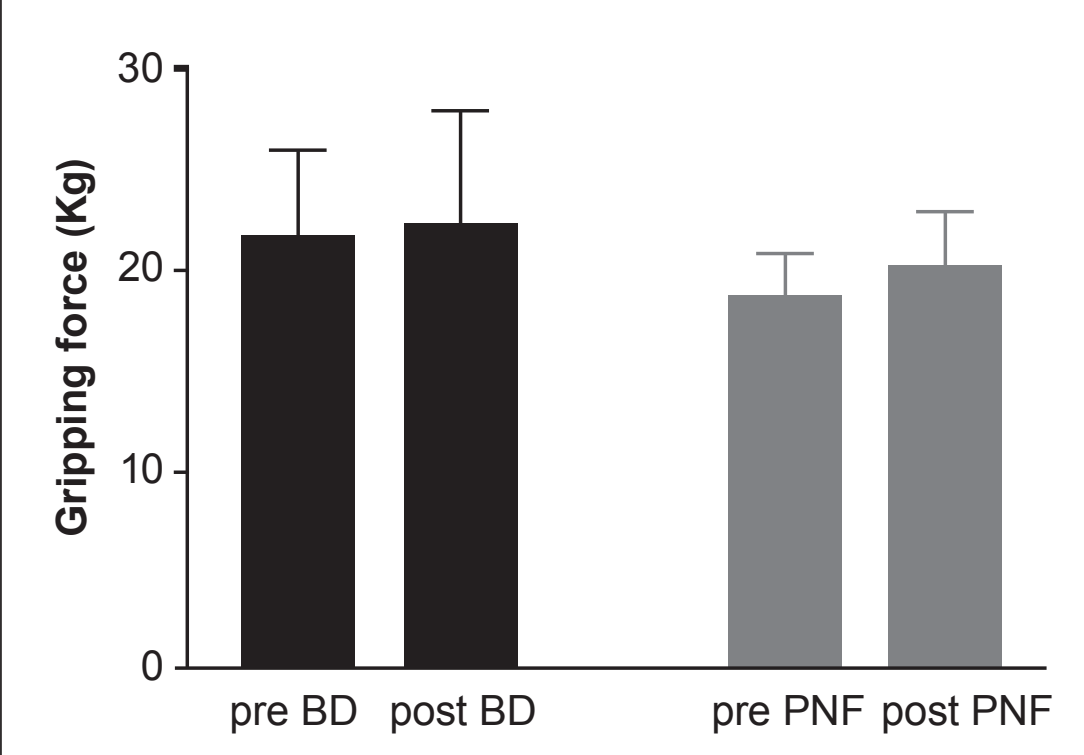

Figure 3. Comparison of gain in grip strength before and after training between the PNF and weight training.

$\mathrm{BD}=$ bodybuilding

$\mathrm{PNF}=$ proprioceptive neuromuscular facilitation

Recife/PE - 2011.

\section{DISCUSSION}

Several studies have paid attention to the aging of the female population, due to this lower incidence of mortality in this genre and its predominance in the elderly population of this group. ${ }^{18,19}$ According to the 2000 Population Census, $55 \%$ of the Brazilian contingent of more than sixty years were women..$^{20}$ Known to that men and women live differently and age. ${ }^{20,21}$ Using data from our study, it was observed that increased life expectancy of elderly women, because in a sample of 17 elderly, 11 were widows, what in percentage equals $64.7 \%$.

The concern in this study population is not only related because it is the majority, but due to physical impairments that are associated, which can cause loss of autonomy and inability to cope with everyday activities. These impairments can lead to increased morbidity and mortality, as they are associated with chronicle diseases ${ }^{16}$, very common in the elderly. According to this study, $5.8 \%$ had tendonitis in the shoulder, $11.7 \%$ had osteoarthritis in the knees, osteoporosis $11.7 \%, 17.6 \%$ RA, $17.6 \%$ diabetic and 17.6\% hypertensive. It could be verified that various associated pathologies that can lead to decreased muscle strength in elderly women. In addition, several physiological changes also occur in women in the aging process, becoming more evident in the menopause. Among these changes is the reduction of female sex hormones, replacement of lean mass by fat tissue, reduced 
muscle mass and decrease in resting energy expenditure. ${ }^{22}$ The senile sarcopenia is due to hormonal changes present in aging, however, the mechanisms of action of female sex hormones on muscle mass, still remain unexplained. ${ }^{23}$

Some studies use force grip to assess the functional capacity of the elderly. ${ }^{22,24}$ Thus, the elderly who have reduced hand grip strength (HGS) are usually sedentary and have deficits in body mass, especially in the flexor muscles of the arm, with functional disabilities in everyday activities. ${ }^{24}$ The literature proposes a normative value of $22.0 \pm 4.7 \mathrm{~kg}$ for the HGS in the elderly aged above 60 years.

In this study, we note that the two groups analyzed were below the predictive index (FG 18.80, and BG 21.57). After the intervention, both groups gained strength, however, only the bodybuilding group reached the predictive value, with the following values: FG 20.10, and BG 22.29. However, in percentage gains, the PNF technique had higher values, with improvement in handgrip strength of $6.91 \%$, while bodybuilding obtained a 3.33\% gain.

Several studies suggested that HGS values equal to or less than $20 \mathrm{~kg}$ are indicative of low functional capacity, and that can lead to morbidity in this population. Looking at it this way, the sample results of the PNF, we see concern, since post-intervention values of the HGS are still below the proposed in the literature. Thus the implementation of physical exercise at BD accounted for an effective way to minimize the physiological effects that occur with aging, improving the picture of hypertension and obesity, thus maintaining physical fitness in the elderly by preventing chronic degenerative changes lead to functional disability. ${ }^{16}$

Currently, studies have shown the importance of resistance training programs to gain strength by stimulating the increase of muscular mass. ${ }^{24}$ This agrees with the findings of this study, which show the period of twelve weeks of intervention as sufficient to achieve muscle strength gains in both techniques, the biceps brachial and quadriceps. However, gains in muscle strength observed occurred in different magnitudes when compared to weight training and PNF techniques, although there was no statistical difference in the two investigated topics.

The authors believe that both techniques had increased strength in their resistance by involving protocols, ie, they use high level of tension to muscle fibers in order to cause a change linked to muscle breakdown, breaking intrasarcomerals links, generating micro-lesions that release cytokines, triggering the mechanism of the inflammatory response in the acute phase. Cytokine production and release of chemoattractive factors are responsible for signaling of circulating monocytes and polymorphonuclear cells in the vascular endothelium. These cells begin the process of chemotaxis, clinging to the wall of the endothelium, leading to movement of "rolling" the capillary blood, to infiltrate the space between the endothelial cells, reaching the injured site. These chemo-attractant factors led to the increase of the intra muscular healing process, with a consequent increase in the number of muscle proteins and, therefore, increased strength. ${ }^{25}$ After this process of diapedesis waste from muscle tissue are then phagocytosed and degraded by macrophages and neutrophils, there is muscle regeneration by releasing growthstimulating factor on satellite cells1. ${ }^{4}$ In addition to this process when there is muscle damage, myoglobin $(\mathrm{Mb})$, the enzyme creatine kinase $(\mathrm{CK})$ and lactate dehydrogenase (LDH) into the circulation going. This is the process that will lead to an increase in myofibrils, and thus muscle hypertrophy and strength gain. ${ }^{26}$

Bodybuilding has been increasingly recommended for the elderly, as it stimulates strength, power, endurance, range of motion $(\mathrm{ROM})$ and coordination. Resistance increases as a result of prolonged stress and load intensity. ROM also increases, due to joint movements required, also collaborating with the coordination. This improvement is due to the fact that the exercises are large and slow, stimulating awareness of the movement. ${ }^{27}$ 
Another associated factor is weight bearing on bones that stimulates increased calcium deposition in the target areas. This process occurs as a result of a negative electrical potential, responsible for the production of osteoblasts in the region of stress, stimulating osteoclastic activity. This process is called "the piezoelectric effect". Therefore, all exercises involving external resistance, such as weight training in addition to generating force, can also help reduce the osteopenic processes. ${ }^{28}$

The proprioceptive neuromuscular facilitation also uses the resistance, but in order to assist in muscle contraction, maximize motor control and assist movement awareness, which leads to an increase in muscle response to the cortex. These stimulated to the cortical region will depend on the intensity of resistance, ie, the greater the resistance, the greater the stimulus, noting that this resistance has to be enough movement occurs smoothly and coordinated, causing no pain or fatigue to patients. ${ }^{29,30}$ Other relevant factors to be considered is that the technique is easy to understand, leading to facilitation of movement throughout its execution, involves strength, coordination and balance, both facilitating, as well as procedures such as diagonal movement patterns and application of sensory stimuli such as auditory, visual, cutaneous and proprioceptive. The PNF also uses manual for contact resistance and stretching, which generates a unit's maximum neuromuscular stimulation. ${ }^{31,32}$

The results of this study with respect to increasing muscle strength, achieved with PNF, may also have been influenced by prior knowledge of the movements and daily use, since the diagonal patterns are used in the technique employed in the activities of daily living of these elderly, as: extending clothes, combing hair, keeping objects in the closet, among other daily activities that may have fostered this increase. ${ }^{33}$ It is also believed that muscle strength, increased during the short treatment period in all groups seems to be the result of improved intra- and intermuscular neural adjustment during the execution of the movement. ${ }^{34}$
In the case of increasing strength in the group trained with PNF, we can infer that the technique has a basic principle the use of fusal stimulus, unleashing a bombing in the neural muscle receptors, causing increased activation of the number of motor units in series, determining increased muscle strength. ${ }^{32}$ There are studies involving muscle training, in order to gain strength; however, they only use the principle of increased resistance, such as weight training, thus ignoring the important physiological effect of neural activation that we described previously. ${ }^{35}$ The authors feel that resistance training with only external resistance increase protocols is more wearing for the elderly, especially as bodybuilding is very common in our midst. The authors recommend the use of techniques based on neural activation and muscle exercises that do not involve high impact, thus preventing articulate degereneration, very common in elderly patients. ${ }^{36,37}$

Therefore, with these results, the authors found that PNF and bodybuilding exercises improved the strength of the biceps and quadriceps of elderly patients; however, the PNF technique seems to be causing the best results in increasing strength.

\section{CONCLUSIONS}

This study found that both groups had an average gain in muscle strength in the brachial biceps, quadriceps and grip, but only the PNF technique obtained statistically significant gains after 12 weeks of intervention. However, when comparing both techniques, there was no statistically significant difference.

Therefore, further studies will be needed in the area of physiotherapy practice in relation to proprioceptive neuromuscular facilitation to gain muscle strength in elderly women, since our society is aging. So it is up to health professionals, particularly physiotherapists, to develop work to prevent the physiological problems that occur with the passing of age and improve the quality of life, as this area lacks health services. 


\section{REFERENCES}

1. Ramos LR. Fatores determinantes do envelhecimento saudável em idosos residentes em centro urbano: Projeto Epidoso. Cad Saúde Pública 2003;19 (3):793-98.

2. Geraldes AAR, Oliveira ARM, Albuquerque RB, Carvalho JM, Farinatti PTV. A força de preensão manual é boa preditora do desempenho funcional de idosos frágeis: um estudo correlacional múltiplo. Rev Bras Med Esporte 2008 Jan/Fev; 14(1):12-6.

3. Matsudo SM, Matsudo VKR, Barros Neto TL. Impacto do envelhecimento nas variáveis antropométricas, neuromotoras e metabólicas da aptidão física. Rev Bras Ciênc Mov 2000 Set;8(4):21-32.

4. Menezes C, Oliveira VRC, Menezes RL. Repercussões da hospitalização na capacidade funcional de idosos. Rev Mov 2010;3(2):76-84.

5. Silva TAA, Frisoli Junior A, Pinheiro MM, Szejnfeld VL. Sarcopenia associada ao envelhecimento: aspectos etiológicos e opções terapêuticas. Rev Bras Reumatol 2006 dez;46(6):391-97.

6. Cadore EL, Brentano MA, Kruel LFM. Efeitos da atividade física na densidade mineral óssea e na remodelação do tecido ósseo. Rev Bras Med Esporte 2005 Nov/Dez;11(6):373-79.

7. Herndon LA, Schmeissner PJ, Dudaronek JM, Brown PA, Listner KM, Yuko Sakano, et al. Stochastic and genetic factors influence tissue-specific decline in ageing c. elegans. Nature 2002;419:808-14.

8. Balagopal P, Schimke JC, Ades PA, Adey D, Nair KS. Age effect on transcript levels and synthesis rate of muscle MHC and response to resistance exercise. Am J Physiol Endocrinol Metab 2001;280(2):E203-8.

9. Larsson L, Sjodin B, Karlsson J. Histochemical and biochemical changes in human skeletal muscle with age in sedentary males, ages 22-65. Acta Physiol Scand 1978;103(1):31-9.

10. Zhong S, Chen CN, Thompson LV. Sarcopenia of ageing: functional, structural and biochemical alterations. Rev Bras Fisioter 2007 Apr;11(2):91-97.

11. Dreyer HC, Volpi E. Role of protein and amino acids in the pathophysiology and treatment of sarcopenia. J Am Coll Nutr 2005 Apr;24(2):140-45.

12. Rebelatto JR, Calvo JI, Orejuela JR, Portillo JC. Influência de um programa de atividade física de longa duração sobre a força muscular manual e a flexibilidade corporal de mulheres idosas. Rev Bras Fisioter 2006 Jan/Mar; 10(1):127-32.

13. Cunha G, Rodrigues. A importância da prática da atividade física em indivíduos idosos. Ed Fís Rev 2010;4(1):1-17.
14. Faria JC, Machala CC, Dias RC, Dias JMD. Importância do treinamento de força na reabilitação da função muscular, equilíbrio e mobilidade de idosos. Acta Fisiatr 2003;10(3):133-37.

15. Gomes TM, Simão R, Marques MC, Costa PB, Novaes JS. Acute effects of two different stretching methods on local muscular endurance performance. J Strength Cond Res 2011 Mar;25(3):745-52.

16. Youdas JW, Haeflinger KM, Kreun MK, Holloway AM, Kramer CM, Hollman JH. The efficacy of two modified proprioceptive neuromuscular facilitation stretching techniques in subjects with reduced hamstring muscle length. Physiother Theory Pract 2010 May;26(4):240-50.

17. Feland JB, Marin HN. Effect of submaximal contraction intensity in contract-relax proprioceptive neuromuscular facilitation stretching. Br J Sports Med 2004 ago;38(4):1-3.

18. Joubert J, Bradshawb D. Population ageing and health Challenges In south Africa. In:Steyn Krisela, Fourie J, Temple N, editors. Chronic Diseases of Lifestyle in South Africa since 1995-2005. Technical report. Cape Town: South African Medical Research Council; 2006. Chapter 15, Population ageing and health challenges in South Africa; p. 204-19.

19. Sauvy A. Population change in Canada to 2017 and beyond the challenges of policy adaptation. Horizons 2007;9(4):3-12

20. Beltrão KI, Novellino MS, Oliveira FEB, Medici AC. Mulher e previdência social: o Brasil e o mundo. Rio de Janeiro: IPEA; 2002. 24 p.(Texto para Discussão; 867).

21. Camarano AA. Mulher idosa: suporte familiar ou agente de mudança?. Estud Av [Internet] 2003 Set/Dez [citado em xx mês xxxx];17(49):3563. Disponível em: http://www.scielo.br/ scielo.php?script $=$ sci_arttext\&pid $=\mathrm{S} 0103$ $40142003000300004 \& \operatorname{lng}=$ en $\& n r m=$ iso

22. Castro JC, Bastos FAC, Cruz THP, Giani TS, Ferreira MA, Dantas EHM. Níveis de qualidade de vida em idosas ativas praticantes de dança, musculação e meditação. Rev Bras Geriatr Gerontol 2009;12(2):255-65.

23. Bonganha V, Santos CF, Rocha J, Chacon-Mikahil MPT, Madruga VA. Força muscular e composição corporal de mulheres na pós-menopausa: efeitos do treinamento concorrente. Rev Bras Ativ Fís Saúde 2008;13(2):102-109.

24. Granacher U, Gruber M, Gollhofer A. Resistance training and neuromuscular performance in seniors. Int J Sports Med 2009 Sept;30(9):652-7. 
25. Rossi E. Envelhecimento do sistema osteoarticular. Einstein 2008;6 Supl 1:7-12.

26. Hansen RD, Allen BJ. Habitual physical activity, anabolic hormones, and potassium content of fat-free mass in postmenopausal women. Am J Clin Nutr 2002 fev;75(2):314-20.

27. Peake JM, Suzuki K, Hordern M, Wilson G, Nosaka $\mathrm{K}$, Coombes JS. Plasma cytokine changes in relation to exercise intensity and muscle damage. Eur J Appl Physiol 2005;95(5-6):514-21.

28. Kraemer WJ, Ratamess NA. Fundamental of resistance training: progression and exercise prescription. Med Sci Sports Exerc 2004 Apr;36(4):674-88.

29. Kofotolis N, Vrabas IS, Kalogeropoulou E, Sambanis M, Papadopoulos C, Kalogeropoulos I. Proprioceptive neuromuscular facilitation versus isokinetic training for strength, endurance and jumping performance. J Hum Mov Stud. 2002: 42 (2):155 -65.

30. O'Hora J, Cartwright A, Wade CD, Hough AD, Shum GL. Efficacy of static stretching and proprioceptive neuromuscular facilitation stretch on hamstrings length after a single session. J Strength Cond Res 2011 Jun;25(6):1586-91.

31. Shimura K, Kasai T. Effects of proprioceptive neuromuscular facilitation on the initiation of voluntary movement and motor evoked potentials in upper limb muscles. Hum Mov Sci 2002;21(1):101-13.
32. Burke DG, Culligan CJ, Holt LE. The theoretical basis of proprioceptive neuromuscular facilitation. J Strength Cond Res 2000 Nov;14(4):496-500.

33. Trampas A, Kitsios A, Sykaras E, Symeonidis S, Lazarou L. Clinical massage and modified proprioceptive neuromuscular facilitation stretching in males with latent myofascial trigger points. Phys Ther Sport 2010 Aug;11(3):91-8.

34. Ryan EE, Rossi MD, Lopez R. The effects of the contract-relax-antagonist-contract form of proprioceptive neuromuscular facilitation stretching on postural stability. J Strength Cond Res 2010 Jul;24(7):1888-94.

35. Souza PML, Jacob-Filho W, Santarém JM, Zomignan AA, Burattini MN. Effect of progressive resistance exercise on strength evolution of elderly patients living with HIV compared to healthy controls. Clinics 2011;66(2):261-6.

36. KAM Z, Dias JMD, Abreu NS, Dias RC. Nível de atividade física, dor e edema e suas relações com a disfunção muscular do joelho de idosos com osteoartrite. Rev Bras Fisioter 2006 Jul/ Set;10(3):279-84.

37. Sun ZJ, Zhang YJ, Sun TZ, Xiong A, Liu RB, Lü HS. [Comparison of the status of STAT4 tyrosine phosphorylation in peripheral T-lymphocytes induced by IL-12 in rheumatoid arthritis and osteoarthritis]. Zhongguo Gu Shang 2011 Apr;24(4): 295-8. 